\title{
EXPERIENCE OF NORTH AMERICAN FORENSIC EXPERTS ON RESEARCHES OF PERSONAGES AS OBJECTS OF THE COPYRIGHT
}

\author{
Kalinichenko M. M., Struk I. O.
}

A personage as a part of literary, visual and audiovisual works is one of intellectual property objects, and thus is the subject to legal protection. The task of forensic expert is an empirical determination of the level of personage independence on the objective evaluation criteria. Therefore, the objective and task of the article is to provide a generalized outline of the main analytical practices and scientific-methodic concepts of North American forensic specialists which are used in the process of case materials evaluation concerning personages as objects of copyright. In the United States, the key legal provision governing the protection of the author rights (the copyright holder) on personage is that such personage is protected to the extent which is defined by the so-called "source identifier" certifying the presence of associative relation of a personage under research with concrete works or commercial objects. The contemporary research also takes into account the "secondary meaning" - factor in the process of personages evaluation, which is based on their value in relation to the source of origin. Forensic experts of the United States also use two main research "tests" to determine whether a personage is a subject to legal protection. The first of them, the so-called "The Character Delineation Test" which is based on the assumption that personages underdeveloped in the artistic sense, give evidence to the lack of obvious signs of author's creativity, hence they are deprived with attributes of creative character represented in the objective form. Another common analytical technique is so-called "The Story Being Told Test" which considers a personage as an integral part of an artistic structure of the analyzed work, without which the work, as a whole, can not exist in accordance with the rules of the traditional artistic logic.

Keywords: copyright, character (personage), reproduction by processing, identifier of source, secondary meaning.

УДК $343.148+347.178$

I. O. Струк, завідувач лабораторії Львівського НДІСЕ,

М. М. Калініченко, науковий співробітник Львівського НДІСЕ, кандидат філологічних наук,

Ю. С. Харабуга, старший науковий співробітник Львівського НДІСЕ

\section{ДОСВІД ПІВНІЧНОАМЕРИКАНСЬКИХ ФАХІВЦІВ ЩОДО ДОСЛІДЖЕНЬ ФОТОГРАФІЧНИХ ТВОРІВ ЯК ОБ'ЄКТІВ АВТОРСЬКОГО ПРАВА}

Розглянуто деякі з провідних аналітичних практик, щео застосовуються північноамериканськими фахівиями в процесі дослідження фактів використання та відтворення шляхом перероблення фотографічних творів як об'єктів інтелектуальної власності (на матеріалах резонансної судової справи «Шепард Фейрі проти Ассоміейтид Прес» 2008 р.).

(C) Струк I. О., Калініченко М. М., Харабуга Ю. С., 2017 
Ключові слова: авторське право, відтворення, використання, перероблення, фотографічний твір.

У сучасну добу цифрових технологій фотографічні твори набули значного поширення й популярності завдяки мережі Інтернет. Через легкий доступ до якісних цифрових примірників світлин недобросовісні особи у своїй господарській діяльності нерідко використовують захищені авторським правом фотографічні твори без отримання ліцензії від авторів або правовласників. Згідно зі статистичними даними, акумульованими північноамериканськими аналітиками, кількість випадків незаконного використання фотографічних творів у світовому центрі фотомистецтва - Сполучених Штатах Америки, невпинно зростає. Під час нещодавнього опитування в США було з'ясовано, що лише за останній рік понад 64 \% американських професійних фотографів безпосередньо стикалися із фактами порушень їх законних прав на фотографічні твори ${ }^{1}$.

Як свідчить судова практика нашої країни, українським фотографам також усе частіше доводиться захищати в судах права на твори, які були незаконно використані або відтворені шляхом перероблення. Можна з упевненістю стверджувати, що кількість подібних судових справ в Україні буде щороку лише зростати. 3 огляду на актуальність цієї проблеми для українських авторів і національного судочинства та перспективу заснування Вищого спеціалізованого суду з інтелектуальної власності, а також беручи до уваги нагальну необхідність створення адекватної офіційної методики дослідження фотографічних творів як об'єктів інтелектуальної власності, досвід фахівців США, які досліджували матеріали судових справ щодо порушення авторських прав на фотографічні твори, має істотну практичну цінність для вітчизняних судових експертів.

Серед величезної кількості судових справ останніх років, у ході яких північноамериканські експерти досліджували факти незаконного використання фотографічних творів як об'єктів авторського права, однією з найбільш резонансних уважається справа «Шепард Фейрі проти Ассошіейтид Прес», відома як «Справа із плакатом Надія» (The Hope Poster Case). Ї̈і обставини були широко висвітлені в пресі та спеціалізованих виданнях, а також детально проаналізовані авторським колективом юристів і професіоналів судової експертизи в розвідці «Роздуми над справою із плакатом Надія» $(2012)^{2}$.

Оглядове вивчення матеріалів зазначеної справи та висновків експертної комісії дозволяє в стислому форматі цієї статті розглянути аналітичні методики дослідження фотографічних творів як об'єктів інтелектуальної власності, котрі ввійшли до арсеналу дослідницьких засобів сучасних північноамериканських фахівців. Таким чином, метою $i$ завданням статті $\epsilon$ узагальнене окреслення основних науково-методичних практик експертної

1 The State of Photo Theft in 2016. URL: https://petapixel.com/2016/12/29/statephoto-theft-2016/ (дата звернення: 19.06.2017).

2 Reflection on the Hope Poster Case / W. W. Fisher III, F. Cost, Sh. Fairey et al. Harvard Journal of Law \& Technology. Vol. 25, № 2, Spring 2012. P. 243-338. 
спільноти США, які широко застосовуються в процесі аналізу фактів несанкціонованого використання фотографічних творів як об’єктів авторського права.

Отже, у січні 2008 р. професійний американський фотограф Ш. Фейрі використав знімок президента Б. Обами (рис. 1) як основу для власного твору - агітаційного поліграфічного виробу із назвою «Плакат Надія» (рис. 2). Цей плакат, а точніше стилізований портрет на ньому, згодом був поширений у різноманітних форматах (на одязі, посуді, сувенірній продукції) та здобув чималу популярність серед американських споживачів. Як наслідок, Ш. Фейрі отримав значні прибутки - понад три мільйони доларів від продажу ліценцій на використання зображення майбутнього президента, а відтворення фотографії Б. Обами у творі «Плакат Надія» мало чіткі ознаки його використання із комерційною метою.

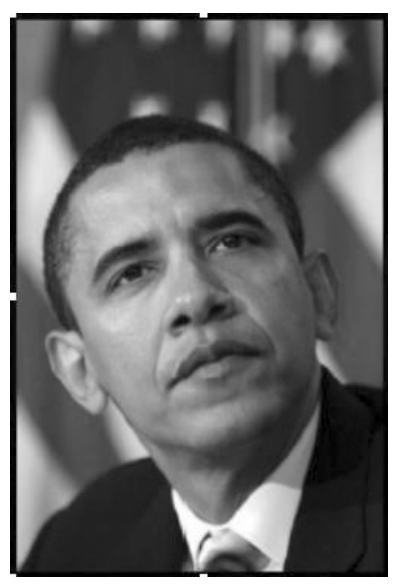

Рис. 1. Знімок президента Б. Обами

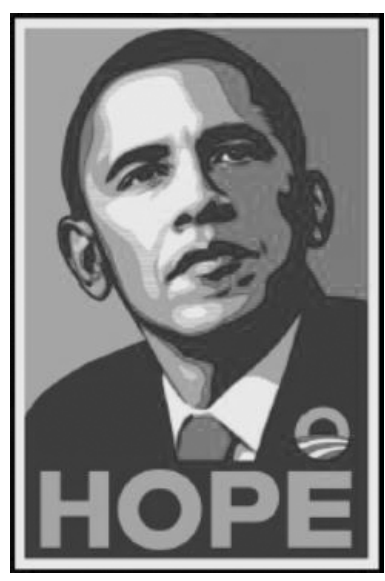

Рис. 1. Ш. Фейрі. «Плакат Надія»

Власники авторських прав на фотографію - відоме агентство новин «Ассошіейтид Прес» (яке заявило про себе як про власника прав на твір), звернулося до Ш. Фейрі з вимогою компенсувати збитки, адже фотограф використав їх фотографічний твір без належного дозволу. Коли перемови щодо можливої мирової зайшли в глухий кут, фотограф апелював до суду із проханням створити комісію експертів і мистецтвознавців, які мали дослідити всі факти та допомогти суду вирішити спір. Справа розглядалася впродовж двох років і зрештою завершилася підписанням мирової угоди, умови якої $є$ конфіденційними. Утім обставини розгляду матеріалів справи «Шепард Фейрі проти Ассошіейтид Прес» експертною комісією добре відомі фахівцям і вважаються своєрідним зразком для наслідування.

На першому етапі дослідження фахівці мали встановити, чи може вважатися створеним творчою працею оригінальним твором фотографія Б. Обами, яка схожа із зображенням на плакаті Ш. Фейрі. Проблема полягає в тому, 
що фотографії (на відміну від малярства) виникають унаслідок складного фізичного процесу фіксації світла фотографічною плівкою або матрицею цифрової камери. Роль автора у створенні фотографічного твору зводиться до певних маніпуляцій із технічними засобами та не передбачає акту творчості в традиційному сенсі (нанесення шарів фарби на площину малюнка). Отже, факт існування творчої праці (або ж оригінальності) фотографії Б. Обами мав бути підтверджений або спростований за допомогою засобів наукового аналізу (дослідження стилістичних особливостей, засобів художнього увиразнення та загальної образної структури твору), які відрізняються від методики дослідження зразків образотворчого мистецтва.

Експерти звернули увагу на те, що американські фотографи регулярно створювали й публікували портрети національних політичних лідерів саме в тому ракурсі (так звана позиція «три чверті»), яким скористалися представники «Ассошіейтид Прес» для створення фотографічного портрета майбутнього президента, сенатора Б. Обами, адже цей ракурс уважається одним із найкращих для увиразнення рис людського обличчя (рис. 3 ). 3 огляду на розповсюдженість цієої техніки зйомки, фотографія «Ассошіейтид Прес» була радше традиційним зразком політичної фотографії, ніж якимось неповторним явищем. Специфіка інших елементів (вираз обличчя суб'єкта зйомки, обриси американського прапора на задньому плані) також не дозволяє вести мову про існування виразної творчої складової фотографії 3 огляду на зазначені особливості техніки фотографування, відмінні від традиційного малювання.

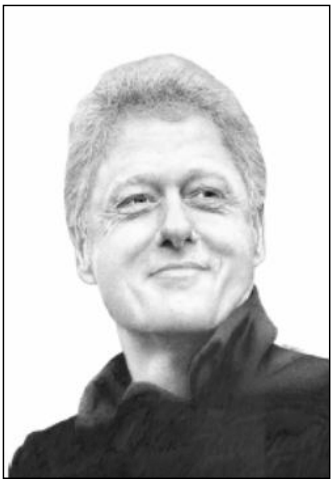

$a$

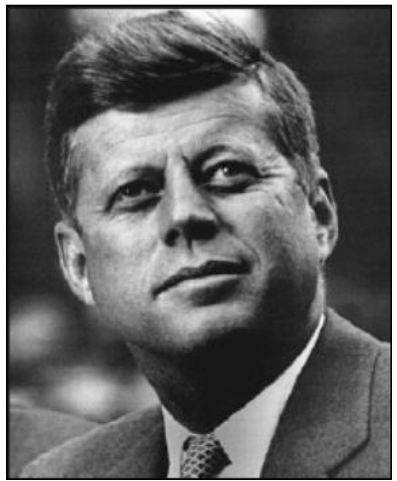

6

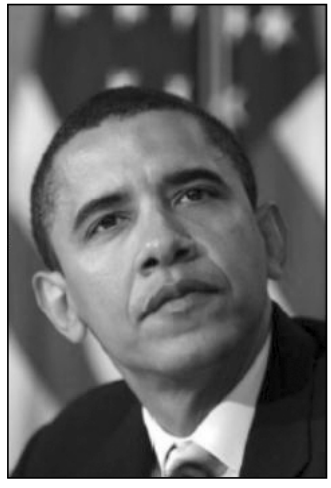

B

Рис. 3. Президенти США Б. Клінтон (a), Дж. Кеннеді (б) та Б. Обама (в)

Цього разу фотограф «Ассошіейтид Прес» лише зафіксував певну політичну подію за участю Б. Обами. Подане на фото обличчя політика на тлі державного прапора, який є одним із загальновідомих символів США, на переконання експертів, також позбавлене помітних ознак оригінальності, адже воно створює у свідомості глядачів цілком природний, очікуваний асоціативний зв'язок зображеної особи та сфери ії професійної діяльності. 
Для прикладу, розтиражоване в безлічі інформаційних джерел агітаційне зображення екс-президента Рейгана на тлі американського прапора $є$ типовим зразком пропагандистської фотографії, помітно схожим на знімок Б. Обами від фотографів «Ассошіейтид Прес» (рис. 4).

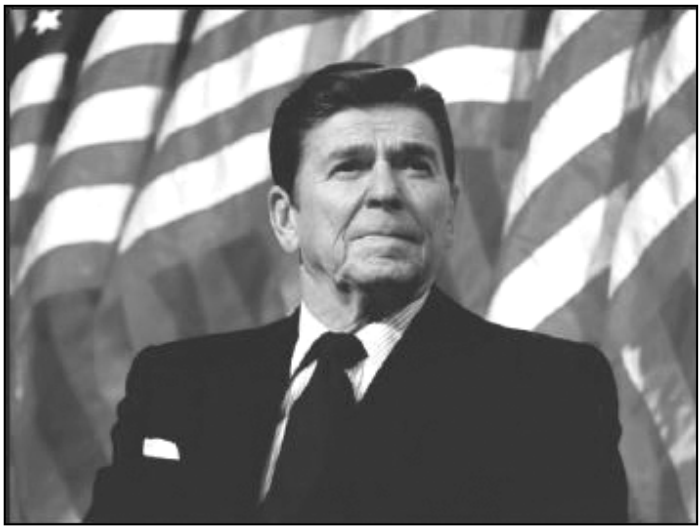

$a$

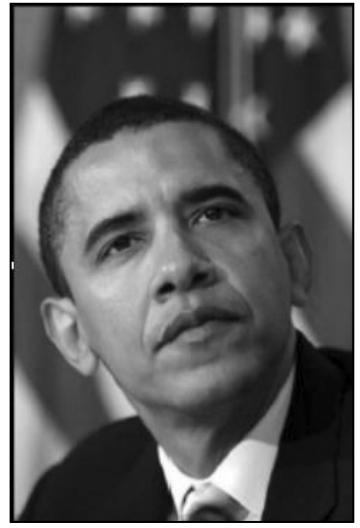

$\sigma$

Рис. 4. Президенти Р. Рейган (a) та Б. Обама (б)

Значно оригінальнішим (завдяки нетиповому поєднанню гетерогенних візуальних складових, які не продукують узвичаєні асоціації за схемою «відома людина та іï професія») у цьому сенсі здаються сучасні сатиричні варіації на тему «Плакату Надія», створені американським художникамигумористами (рис. 5.) на основі твору Ш. Фейрі. Разом із тим, дослідивши інформацію на жорстких дисках комп’ютерів у студії Ш. Фейрі, експерти встановили, що фотограф дійсно використав шляхом перероблення фотографічний твір, що належав «Ассошіейтид Прес».
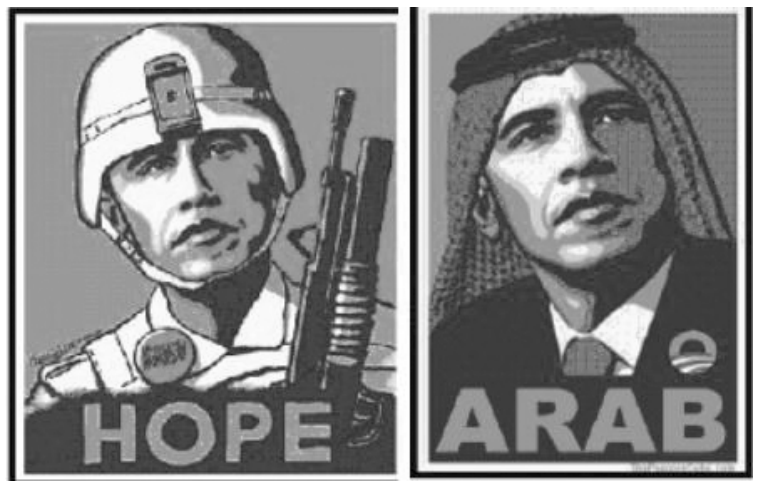

Рис. 5. Сучасні сатиричні варіації на тему «Плакату Надія» 
На другому етапі дослідження експерти мали визначити рівень так званої «трансформативності» «Плакату Надія» (тобто рівень творчих візуальних перетворень), що б дозволило представникам Ш. Фейрі під час захисту в суді апелювати до відомої в США доктрини «добросовісного використання» (The Fair Use Doctrine). Відповідно до їі базових положень за наявності достатньої кількості творчих перетворень (їх сутність і кількість зазвичай визначаються експертами), відтворений шляхом перероблення твір визнається достатньо оригінальним, а отже, відмінним від свого першоджерела настільки, щоб не вважатися порушенням авторських прав.

Представники експертної комісії звернули увагу суддів на той факт, що історикам мистецтва відома значна кількість випадків, коли популярні художники використовували фотографії інших авторів як образні підгрунтя для власних творів, але суттєво «трансформували» елементи цих світлин перетворювали їх у такий спосіб, що кінцевий витвір набував цілком очевидних ознак оригінальності й творчої праці (рис. 6). Як бачимо, портрет зображеної особи істотно відрізняється від фотоджерела завдяки використанню Ван Гогом особливої техніки художньої стилізації (стиль сюрреалізму), котра в специфічний спосіб увиразнює елементи зовнішності репрезентованої особи та «віддаляє» ¥ї загальний образ від тієї «реалістичної» манери зображення, яка подана на світлині. Як наслідок, обидва твори є загалом подібними на рівні композиції, утім, порівняно з фотографією, малюнок має достатньо високий рівень «трансформативності» для того, аби вважатися оригінальним результатом творчої праці.

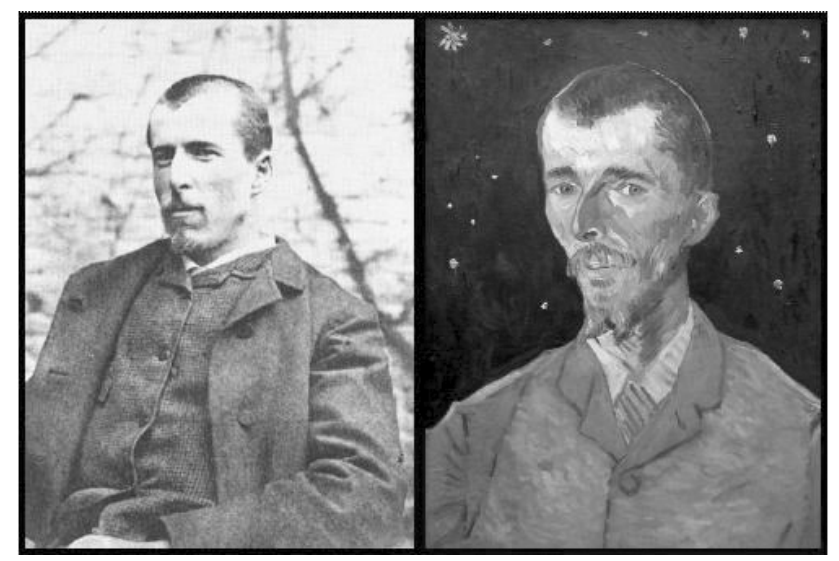

Рис. 6. Фотопортрет і портрет, виконаний Ван Гогом

У процесі аналітичного зіставлення графічної структури фотографії «Ассошіейтид Прес» і «Плакату Надія» комісія експертів установила, що портрет Б. Обами на площині малюнка Ш. Фейрі має помітні відмінності (рис. 7) порівняно з образом президента на фотографічному творі. Разом із тим, на думку фахівців, сутнісні характеристики цих візуальних відміннос- 
тей «Плакату Надія» не дозволяють вести мову про високий рівень «трансформативності».

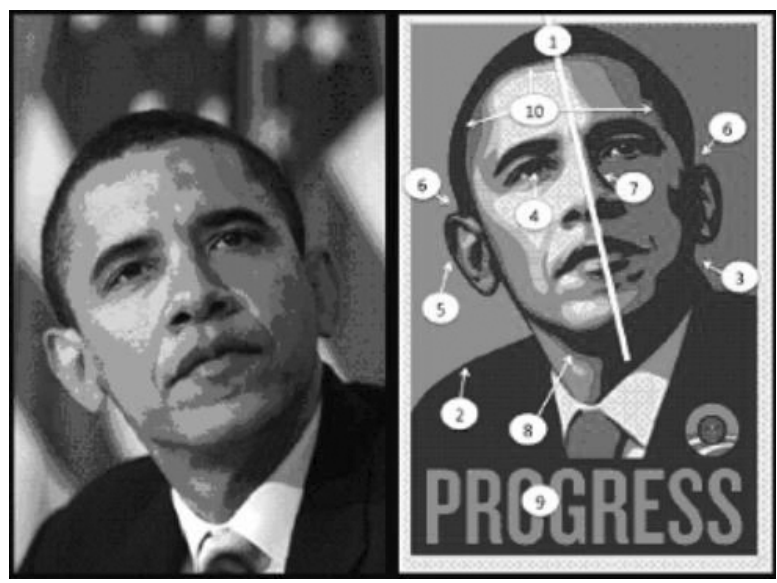

Рис. 7. Відмінності малюнка Ш. Фейрі порівняно з фототвором

Експерти дійшли висновку, що перетворення фотографії на малюнку Ш. Фейрі відбулися головним чином завдяки використанню найчастіше вживаних функцій програмних засобів редагування цифрових зображень. По суті, зображення людини на «Плакаті Надія» є добре відредагованим (переважно в автоматичному режимі) фотопортретом Б. Обами за авторством майстрів 3 «Ассошіейтид Прес», який не має достатнього рівня «трансформативності» саме завдяки тому, що Ш. Фейрі не перемальовував в індивідуальній творчій манері, а лише редагував оригінальний знімок президента, хоча й здійснив чималу кількість операцій із графічними редакторами для створення кінцевого варіанта твору. Як зазначено в матеріалах справи, запрошений до судової зали спеціаліст з редагування цифрових фотографій, зумів за 19 хв створити майже ідентичний варіант «Плакату Надія» на основі фотографії «Ассошіейтид Прес» за допомогою засобів автоматичного покращення зображення, наявних у переважній більшості сучасних графічних редакторів. Отже, справжнім творцем «Плакату Надія» за авторством Ш. Фейрі по суті були алгоритми комп’ютерної програми, а не вправна рука талановитого художника.

Висновки експертів щодо доволі низького рівня творчої «трансформативності» «Плакату Надія» заслуговують на особливу увагу теоретиків судової експертизи та мистецтвознавців, адже цього разу маємо справу із незвичним феноменом художньої творчості, яка реалізується за допомогою комп'ютерних інструментів, використання яких мінімізує роль автора-творця в процесі створення й редагування цифрових зображень. Цілком можливо, що інша комісія експертів, краще обізнаних із поширеною серед сучасних художників-постмодерністів технікою графічних колажів (які формуються 
в автоматичному або напівавтоматичному режимі) могла б по-іншому визначити рівень творчих перетворень «Плакату Надія» порівняно з фотографією «Ассошіейтид Прес».

Наприкінці дослідження комісія експертів дійшла таких висновків:

— фотографія Б. Обами, створена фотографами з агенції «Ассошіейтид Прес», не може вважатися оригінальним твором;

— графічний твір «Плакат Надія» за авторством Ш. Фейрі було визнано відтворенням (шляхом перероблення) фотографічного твору «Ассошіейтид Прес»;

- 3 огляду на низький рівень «трансформативних» творчих перетворень зображення Ш. Фейрі, його твір не відповідає положенням «Доктрини добросовісного використання».

Як було вже зазначено, висновки комісії експертів змусили учасників судової справи підписати угоду про примирення, конкретні умови якої все ще не розголошуються представниками сторін.

Подальше вивчення багаторічного досвіду північноамериканських експертів сприятиме утвердженню нових дослідницьких методик і загальній оптимізації проведення судових експертиз у сфері захисту авторського права. 3 огляду на те, що українським спеціалістам наразі бракує офіційної методики, яка визначить загальноприйняті принципи та стандарти дослідження фотографічних творів як об’єктів інтелектуальної власності, науково-методичні настанови закордонних аналітиків можуть стати корисним джерелом актуальної інформації щодо найефективніших практик сучасної судової експертизи світового рівня.

\title{
ОПЫТ СЕВЕРОАМЕРИКАНСКИХ СПЕЦИАЛИСТОВ ПО ИССЛЕДОВАНИЯМ ФОТОГРАФИЧЕСКИХ ПРОИЗВЕДЕНИЙ КАК ОБЪЕКТОВ АВТОРСКОГО ПРАВА
}

\author{
Струк И. А., Калиниченко М. М., Харабуга Ю. С.
}

Рассмотрены некоторые из руководящих аналитических практик, применяемых североамериканскими специиалистами в процессе исследования фактов использования и воспроизведение путем переработки фотографических произведений как объектов интеллектуальной собственности (по материалам резонансного судебного дела «Шепард Фейри против Ассошиэйтид Пресс» 2008 г.).

Ключевые слова: авторское право, воспроизведение, использование, переработка, фотографическое произведение.

\section{EXPERIENCE OF NORTH AMERICAN SPECIALISTS ON RESEARCHES OF PHOTOGRAPHIC PRODUCTS AS OBJECTS OF THE COPYRIGHT}

\section{Struk I. O., Kalinichenko M. M, Harabuga Yu. S.}

In the modern epoch of digital techniques the photographic works gained considerable popularity and widespread use through the Internet. Because of easy access to the highquality digital copies of photographs, unfair individuals in their business activities often 
use copyrighted photographic works without a license from the authors or copyright holders. Taking into account the actuality of this problem for the Ukrainian authors and national legal system, considering the prospect of establishing the High Specialized Court for Intellectual Property, and also in view of the urgent need of creating an adequate official technique for the research of photographic works as intellectual property objects, the experience of the United States specialists who studied the materials of court cases concerning infringement of copyright to the photographic works, has a significant practical value to the forensic experts of our country. Review study of the high profile case "Shepard Fairey v. the Associated Press», known as "The Hope Poster case», as well as the conclusions of the expert commission, allows to consider main analytical techniques of research on photographic works as intellectual property objects, which have entered into the range of research means of modern North American court experts. The expert committee for this case reached the following conclusions: the photograph of B. Obama, created by photographers from the agency "Associated Press", cannot be considered as an original work; the graphic work under the title "The Hope Poster» authored by Sh. Fairey was found to be a variation of the photographic work of "The Associated Press»; in consideration of the low level of creative "transformativeness" of the image in the work of Sh. Fairey, his poster does not meet the conditions of the «Fair Use Doctrine». The findings of the experts forced the parties of court case to sign a conciliation agreement on such terms which are still not disclosed.

Keywords: copyright, reproduction, use, processing, photographic product. 